VOX PATRUM 26 (2006) t. 49

Ks. Stanisław LONGOSZ

(Lublin, KUL)

\title{
MARYJA W APOKRYFACH STAREGO TESTAMENTU
}

Nieliczne dane biograficzne o Maryi w Biblii zostały obficie uzupełnione w powstających od II wieku apokryfach. Niektóre z nich ze względu na swą treść, dotyczącą dziecięctwa Jezusa i Jego Matki Maryi, jak i jej odejścia (transitus) $\mathrm{z}$ tego świata, nazywane bywają apokryfami maryjnymi ${ }^{1}$. One to

${ }^{1}$ Por. S.A. Campos, Corpus Marianum Patristicum (= CMP), I-V, Burgos 1970-1974, I nr 312 368, II nr 1460-140, III nr 2901-2924, V nr 5679-5930 (teksty apokryfów o Maryi); M. Chaine (ed.), Apocrypha de Beata Maria Virgine, CSCO 39 (tekst), 40 (przekład),Paris 1909; H.D. Rops, Les Évangiles de la Vierge, Paris 1948; E. Cothenet, Marie dans les apocryphes, w: Maria. Études sur le Sainte Vierge, red. H. du Manoir, VI, Paris 1961, 71-156; VIII, Paris 1971, 121 (index analitique: Apocryphes); P.G.M. Roschini, Mariologia, I, Romae 1957, 68-76 (De apocryphis marianis); A.C. Rush, Maria en los Evangelios apocrifos, w: J.B. Carol, Mariologia, Madrid 1964, 56-181; G. Söll, Mariologie, HDG III 4, Freiburg - Basel 1978, 24-30 (Das Marienbild der Apokryphen); M. Dobraczyńska, Co mówiq o Matce Bożej apokryfy, DzJ 7 (1951) nr 26, s. 6; S.C. Mimouni, Les Apocalypses de la Vierge: état de la question, ,Apocrypha” 5 (1994) 211-248; F. Morard, L'Évangile de Marie: un message ascétique, „Apocrypha” 12 (2001) 155-173; E. Norelli, Maria nella letteratura apocrifa dei primi secoli, „Theotokos” 9 (2001) 191-225; tenże, La Vergine Maria negli apocrifi, w: C. Leonardi - A. Degli Innocenti (ed.), Maria. Vergine, Madre, Regina, Roma 2000, 21-42; tenże, Maria negli apocrifi, w: C.M. Piastra (ed.), Gli studi di mariologia medievale. Bilancio storiografico. Atti del Convegno della Fondazione Ezio Franceschini (Parma, 7-8 XI 1997), Firenze 2001, 19-63; R. Laurentin, Mythe et dogme dans les apocryphes, w: De primordiis cultus mariani, IV, Romae 1970, 13-29; P.E. Langevin, Les écrits apocryphes du Nouveau Testament et la Vierge Marie, tamże, 233-252; G. Gharib, Maria di Nazaret secondo gli apocrifi, Roma 2001; Marie dans les récits apocryphes chrétiens, t. 1: Communications présentées à la $60^{\circ}$ Session de la Société Française d'Études Mariales (Solesmes 2003), red. J. Longere, Médiaspaul 2004; J. Rothen, Marie et les apocryphes, tamże ss. 13-52; Y.M. Blanchard, La Mère de Jesus dans les apocryphes de la tradition Johannique, tamże, s. 65-80; J. Évenou, Des apocryphes à la liturgie: les origines du culte de sainte Anne, tamże, s. 201-226; Enciclopedia mariana „Theotokos”, Genova - Milano 1954, 10-12 (Annotazioni sugli apocrifi mariani); J. Schmid - W.J. Hoffmann - P. Herzog - H. Tristram, Maria in Apokryphen-Literatur-geschichte, w: Marienlexikon, Bd. 1, St. Ottilien 1988, 193-201; E. Peretto, Apocrifi, w: Nuovo Dizionario di mariologia, red. S. De Fiore - S. Meo, Milano 1986, 96-113; L.M. Peretto, Maria, BS VIII 830-838 (Maria nella letteratura apocrifa); P.G.M. Roschini, Mariologia, I, Romae 1957, 68-76 (De apocryphis marianis); M. Starowieyski, Apokryfy Nowego Testamentu (= ANT), I/1: Ewangelie apokryficzne, Kraków 2003², 851-852 (Bibliografia: Mariologia); III: Listy i apokalipsy, Kraków 2001, 360-361, 370-371; S. Longosz, Maryja w apokryfach, EK XII (w druku). 
również, jak Pismo św., dzielą się na apokryfy maryjne Nowego i Starego Testamentu, choć niektóre z tych drugich, mimo swej tematyki przedchrześcijańskiej, układane przez autorów chrześcijańskich lub przez nich interpolowane, zaliczane są do apokryfów Nowego Testamentu. Wszystkie one wyrażając ludową szczerą wiarę, kult i przekonania starały się uzupełnić brakujące w Biblii biograficzne wątki w życiorysie Maryi, by ją wychwalać lub bronić przed szkodzącymi jej postaci błędami. Najwięcej oczywiście wiadomości na jej temat dostarczają nam apokryfy Nowego Testamentu, my jednak zajmiemy się tu czterema apokryfami zaliczanymi do grupy Starego Testamentu, które również od samego powstania lub wskutek późniejszych interpolacji zawierają pewne wątki maryjne, najczęściej zapowiadające lub podkreślające dziewictwo rodzicielki przyszłego Mesjasza. W niniejszym przyczynku najpierw szczegółowiej zostaną przypomniane maryjne wątki apokryfów Starego Testamentu, a następnie łącznie z apokryfami Nowego Testamentu ich wpływ na rozwój teologii i kultu maryjnego.

Do maryjnych apokryfów Starego Testamentu zaliczane są najczęściej:

1. Testamenty dwunastu Patriarchów (ClApVT 118) - zawierające przedśmiertne wypowiedzi synów patriarchy Jakuba, autorstwa prawdopodobnie jakiegoś żyda żyjącego w diasporze w Aleksandrii lub w Syrii, piszącego po grecku w czasach panowania Jana Hirkana (134-104 prz. Chr.), później jednak za czasów chrześcijańskich wielokrotnie interpolowane. Przedostatni z nich Testament Józefa opowiadający m.in. jak udało mu się uniknąć zwodniczych sideł kobiety oraz zachęcający do wzajemnej miłości i przebaczenia, wspomina też wizję senną tegoż patriarchy, że ,z Judy narodziła się Dziewica mająca szatę z bisioru, z której pojawił się Baranek bez skazy, a po lewej jego stronie jakby lew. Wszystkie dzikie zwierzęta uderzyły na Niego, ale zwyciężył je Baranek, zniszczył je i zostały zdeptane" ${ }^{2}$. Nie trudno zauważyć, że powyższa wzmianka o Dziewicy w szacie z bisioru, która urodziła Baranka bez skazy, a wskazująca na Maryję Dziewicę, Matkę Chrystusa, jest późniejszą interpolacją, dokonaną prawdopodobnie na początku II wieku przez jakiegoś chrześcijanina, związanego ze szkołą św. Jana Apostoła, autora Apokalipsy.

2. Wniebowstapienie Izajasza (ClApNT 315) - ułożony w języku greckim przez chrześcijanina na pocz. II wieku, a zachowany w wersji etiopskiej i łacińskiej apokryf, opisujący ekstazę Izajasza i jego podróż po 7 niebach, gdzie widzi wiele tajemnic dotyczących Chrystusa i Kościoła: wśród nich widzi tajemnicę wcielenia z dziewiczym poczęciem i urodzeniem, jednakże bezcielesnego Syna. Interesujący nas fragment (11, 2-15), będący w pierwszej części rozwinięciem ewangelicznych treści św. Mateusza $(1,18-2,1)$ podkreśla przede wszystkim

2 Por. Testamenta XII patriarcharum. Testamentum Josephi 19, ed. R.H. Charles, The Greek versions of the Testaments of the Twelve Patriarchs, Oxford 1908 (ristam. Hildesheim 1960) s. 210; CMP I 339; tłum. A. Paciorek, w: Apokryfy Starego Testamentu, oprac. R. Rubinkiewicz, Warszawa 1999, 78 . 
dziewictwo Maryi przed i w czasie narodzenia, o którym początkowo nie wiedział nie tylko sam św. Józef, który chciał ją odesłać, ale i mieszkańcy Betlejem: Maryja po urodzeniu Jezusa pozostała taką samą dziewicą, jak przed i w czasie Jego poczęcia. Treść tego fragmentu zdaje się sugerować, że narodzenie Jezusa, opisane w kategorii wizji, nie było prawdziwe, neguje Jego cielesność, co być może zdradza doketyczne poglądy autora tego opisu, choć Maryja i Józef rozpoznali prawdziwą naturę Jezusa, która dla aniołów i dla mieszkańców Betlejem pozostawała zakryta i nierozpoznana. Jest w nim także zaznaczone, że Maryja i Józef byli prawdziwym małżeństwem, w którym nie tylko on, ale również ona pochodziła z rodu Dawida, o czym kilkakrotnie zaznaczał również żyjący w II wieku Justyn apologeta ${ }^{3}$.

3. Ody Salomona (CPG 1350; ClApVT 205) - powstałe w II wieku jako utwory liturgiczne gnostyckiego pochodzenia, w pełnym symboli języku syryjskim. Oda XIX opowiada o dziewiczym zrodzeniu zarówno nowego świata, jak i Jezusa, Syna Dziewicy, której nie dotknęły bóle rodzenia i która urodziła bez udziału męża, pozostając nadal dziewicą. W kilku jej wersetach (6-11) ukazane jest przede wszystkim doskonałe dziewictwo Maryi, przed, w trakcie poczęcia i urodzenia Jezusa, która z własnej woli, jak mężczyzna, pozostała dziewicąmatką. Nietknięte dziewictwo Maryi, nawet podczas Jego narodzin, podkreślone jest również przez to, że urodziła Go bez jakichkolwiek cierpień i bez pomocy akuszerki ${ }^{4}$. To świadectwo XIX ody Salomona o doskonałym dziewic-

${ }^{3}$ Por. Ascensio Isaiae 11, 2-15, ed. E. Tisserand: Ascension d'Isaiae. Traduction de la version éthiopienne avec les principales variantes des versions grecque, latine et slave. Introduction et notes, Paris 1909, 202-206; ed. P. Bettiolo, CCAp 7, 118-120 (tekst etiopski + przekład włoski); CMP I 312; tłum. S. Kur w: Apokryfy Nowego Testamentu, III, Kraków 2001, 160-161: „Ja zaś ujrzałem niewiastę z rodu proroka Dawida, której na imię Maryja. A była dziewicą i została poślubiona mężowi, któremu na imię Józef, cieśla; on także był z nasienia i rodu Dawida sprawiedliwego, który był z Betlejem judzkiego. I przyszedł do swego przeznaczenia. Gdy zaś została poślubiona, została znaleziona brzemienną i Józef cieśla chciał ją odesłać. Ale anioł Ducha zjawił się w tym świecie i potem Józef nie odesłał jej, ale strzegł Maryję, a sam nie wyjawił nikomu tej sprawy. Nie zbliżał się do Maryi i zachował ją jako dziewicę świętą, choć była brzemienna. I nie mieszkał z nią przez dwa miesiące. A po dwóch miesiącach czasu Józef był w domu i [także] Maryja jego małżonka, oboje tylko sami. Stało się, gdy byli sami, że Maryja spojrzała swoimi oczami i zobaczyła małe dziecko i przestraszyła się. Potem jak się zmieszała, jej łono stało się jak było przedtem, zanim poczęła. A gdy jej mąż Józef powiedział do niej : «Dlaczego jesteś przestraszona?» otwarły się jego oczy, zobaczył dziecko i wielbił Boga, gdyż Pan przyszedł do swego przeznaczenia. I doszedł do nich głos: «Nikomu nie mówcie o tym widzeniu». I rozeszła się wieść o dziecku w Betlejem. I byli tacy, którzy mówili: «Maryja dziewica urodziła, zanim upłynęły dwa miesiące, od kiedy została poślubiona». I mówiło wielu: «Nie zrodziła, ani nie przyszła położna», nie słyszeliśmy krzyku bólu». Byli ślepi wszyscy w jego sprawie i nikt nie wierzył w Niego, nie wiedzieli, skąd jest. Zabrali go i przyszli do Nazaretu Galilejskiego", zob. komentarz: E. Norelli, CCAp 8, 538-561; P.F. Buck, Are the „Ascension of Isaiah" and the „Odes of Salomon” witness to an early cult of Mary?, w: De primordiis cultus Mariani, IV, Romae 1979, 371-400; Justinus, Dialogus cum Judaeo Tryphone 43, $1 ; 45,4 ; 68,6 ; 100,3$.

${ }^{4}$ Por. Odae Salomonis XIX 6-11, ed. R. Harris, The Odes and Psalms of Salomon, II, Manchester 1920, 288-289; CMP I 358-359, tłum. M. Starowieyski: Apokryfy Nowego Testamen- 
twie Maryi musiało być znane w starożytności, bo na początku IV wieku powołuje się na nie w łacińskim brzmieniu na równi $\mathrm{z}$ wypowiedzią proroka Izajasza, że Dziewica pocznie i porodzi Emanuela (Iz 7, 14), afrykański nauczyciel retoryki w Nikomedii Laktancjusz (250-330) $)^{5}$. O „,doskonałej dziewicy", która staje naprzeciw Uwodziciela i wzywa do siebie synów ludzkich, by nie szli za nim, by go porzucili, a ona uczyni ich mądrymi i zapewni im zbawienie, mówi również XXXIII oda Salomona ${ }^{6}$; toczy się od dawna dyskusja, czy chodzi tu jednak o Maryję, choć większość współczesnych badaczy odmawia temu tekstowi maryjnego charakteru.

4. Wyrocznie Sybillińskie (ClApNT 319) - ułożone na przełomie II/III wieku wierszem po grecku w XIV księgach, w większości przez chrześcijan. Fragment księgi VIII, będący parafrazą Łk 1, 26-38, opisuje zwiastowanie przez Gabriela, dziewicze poczęcie i dziewicze urodzenie Syna w Betlejem przez Maryję. W interesującym nas fragmencie autor najpierw podkreśla, że Mesjasz

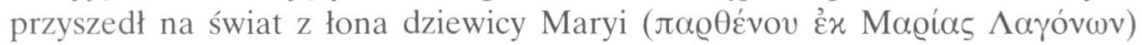

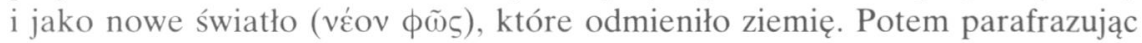
relację św. Łukasza o zwiastowaniu, stara się odtworzyć samą scenę zwiasto-

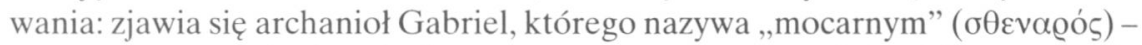
przez co autor zdradza, że jest mu znane podstawowe hebrajskie znaczenie tego imienia - i zwraca się do Maryi, którą nazywa „niewinną dziewczyną"

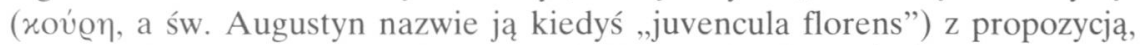
a nawet delikatnym poleceniem: „przyjmij, dziewico ( $\pi \propto \varrho \theta \varepsilon \dot{v \varepsilon})$, Boga do swe-

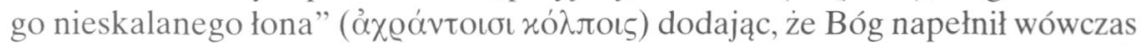

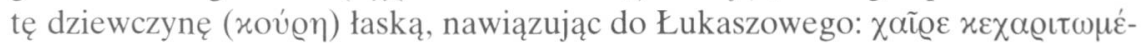
vย. Autor stara sie również odtworzyć psychologicznie reakcję Maryi na tę

tu, I, Kraków 2003, 155: „Łono Dziewicy poczęło, macica otrzymała, ona porodziła Dziewica stała się matką wśród wielkiej miłości. Stała się brzemienna, zrodziła Syna i nie cierpiała. A to nie było bez powodu, nie potrzeba jej było akuszerki, bo On ją ożywiał. Zrodziła jak mężczyzna, z własnej woli, Zrodziła jako przykład, I otrzymała w mocy Umiłowała zbawienie Zachowała w słodyczy, Okazała w majestacie”; zob. J.M. Bover, La mariología en las Odas de Salomon, „Estudio Eclesiásticos” 10 (1931) 349-363; P.F. Buck, Are the „Ascension of Isaiah” and the „Odes of Salomon” witnesses to an early cult of Mary?, art. cyt., s. 371-400; F.J. Pierre, La Vierge dans les „Odes de Salomon", w: Marie dans les récits apocryphes chrétiens, Médiaspaul 2004, 119-138; B. Horn, The Virgin and the Perfect Virgin. Traces of Early Eastern Christian mariology in the „Odes of Solomon", StPatr 40 (2006) 413-428.

5 Por. Lactantius, Divinae institutiones IV 12,3, CSEL 19, 310: ,Solomon in ode undevicesima ita dicit: «infirmatus est uterus virginis et accepit fetum, et gravata est et facta est in multa miseratione mater virgo".

6 Por. Odae Salomonis XXXIII 1-9, ed. Harris, II, 374-375, CMP I 360; „, Naprzeciw niego stała doskonała dziewica, która wołała i krzyczała mówiąc: «Synowie ludzcy, wracajcie, wy i wasze córki. Porzućcie drogi tegoż uwodziciela i zbliźcie sie do mnie. Chcę do was wejść i uchronić was od ruiny, chcę was uczynić mądrymi na drodze prawdy. Nie niszczcie się, a nie zginiecie. Słuchajcie mnie, a ocalejecie; dzięki łasce Boga pojawiłam się wśród was: ja jestem sędzią waszym. Ci, którzy mnie przyjęliście, zachowacie nieskazitelność na nowej ziemi»”. 
propozycję: najpierw była nią zdumiona i przerażona, a później uradowana i uśmiechnięta, wyrażając przez to swą zgodę; wówczas Słowo Boże zamieszkało w jej dziewiczym łonie, stało się ciałem i przybrało postać człowieczą, a później jako dziewiczo poczęty chłopiec się narodziło, a ziemia powitała Go z radością jako maleńkie Dziecię. Autor podkreśla, że tego rodzaju dzie-

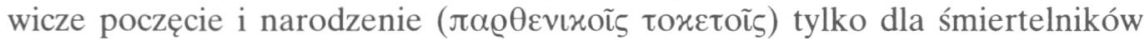
było ogromnym cudem, dla Boga Ojca zaś i Syna Bożego nie było czymś wielkim. Autor zna jednak nie tylko relację św. Łukasza opowiadającą o Dziecięciu w pieluszkach ( $\mathrm{kk} 2,7,12,16)$ i o pasterzach strzegących owce, woły i kozy (2, 8-17), ale i św. Mateusza, piszącego o gwieździe betlejemskiej i mędrcach (Mt 2,2) ${ }^{7}$. Autor tego analizowanego fragmentu chciał podkreślić przede wszystkim pełne dziewictwo Maryi - zarówno przy poczęciu jak i przy narodzeniu Chrystusa.

Także w innych miejscach Wyroczni Sybillińskich spotykamy drobne bezimienne wzmianki lub aluzje do Maryi jako dziewicy, choć nie zawsze nazywana jest ona wprost „dziewicą”, ale tylko „dziewczyną”. Czytamy wiec w nich m.in. o dziewczynie ( $\delta \alpha \dot{\mu} \mu \alpha \lambda \iota \varsigma$ ), która porodziła Słowo Boga Najwyższego, nadała Mu imię, a świecąca jasno w dzień gwiazda na wschodzie głosiła Go światu z nieba że Bóg przeniósł „na świętą dziewicę” (

7 Oracula Sibyllina VIII 456-479, ed. A. Kurfess: Sibyllinische Weissagungen und Übersetzung, München 1951, 182-184; ed. J. Geffcken, GCS 8, 171-172; CMP I 357, tłum. W. Appel, w: Apokryfy Nowego Testamentu, I, Kraków 2003, 156-157: „W czasach najnowszych zaś ziemię odmienił, gdy z łona dziewicy Marii przyszedł na świat i nowe światło wydobył. Z niebios zstępując, postać na siebie przyjął człowieczą. Najpierw więc Gabriel mocarną swą postać objawił, po czym archanioł słowem się ozwał do czystej niewiasty: «Przyjmij Boga twym nieskalanym łonem, dziewico». Rzekł tak Bóg i łaską wypełnił czystą niewiastę; ją zaś te słowa wprawiły w zdumienie i trwogę zarazem, stała więc drżąca, a serce spłoszone w jej piersi się tłukło burząc myśli, bo głos posłyszała zupełnie nieznany. Później wszakże ów głos ją ucieszył i wzbudził w niej radość; wówczas uśmiech weselny rumieńcem zabarwił jej lica, radej przyszłą radością i zbożnym tchnieniem natchnionej. Lęk ją opuścił, a Słowo naonczas zapadło w jej łono, z czasem ciałem się stało żyjącym pod piersią matczyną; postać człowiecza powstała i tak dziewiczo poczęty chłopiec się zrodził; cud to ogromny dla ludzi śmiertelnych, cud zaś żaden dla Boga Rodzica i Syna boskiego. Ziemia z wielką radością witała to dziecię maleńkie, wszechświat cześć mu oddawał, a tron na niebiosach się cieszył. Nowa zaś jasna gwiazda, prorocza, rozbłysła dla mędrców, w żłobie zaś dziecię w pieluszkach pobożnym się ukazało stróżom wołów i kóz, a także owiec pasterzom, Tak Betlejem Słowa stało się Bożą ojczyzną”; zob. J.B. Bauer, Die Messiasmutter in den „Oracula Sibyllina”, „Marianum” 18 (1956) 118-124.

${ }^{8}$ Por. Oracula Sibyllina I 323-326, ed. Kurfess, s. 48; CMB I 354: „Kiedy dziewczyna porodziła Słowo Boga, a nie mając męża nadała Słowu imię, wtedy świecąca jasno we dnie na wschodzie gwiazda ogłosiła go z nieba”.

${ }^{9}$ Por. tamże VIII 265-270; ed. Kurfess, s. 174; GCS 8, 159; CMB I 355: „Wszechmogący powiedział: «Uczyńmy, Synu, obaj śmiertelników na nasz obraz: ja teraz rękami, ty zaś potem słowem uleczysz naszą postać, abyśmy jej nadali wspólną strukturę?» Pamiętając zatem o tej postaci zstąpi na stworzenie przenosząc podobny obraz na świętą dziewicę". 


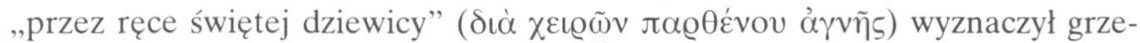
szącym ludziom siedem wieków pokuty ${ }^{10}$.

O wiele więcej informacji o Matce Bożej dostarczają nam apokryfy maryjne Nowego Testamentu, które poświęcone są już w całości życiu Maryi, zwłaszcza jej dziecięctwu, młodości, zwiastowaniu i urodzeniu Jezusa oraz ostatnim chwilom jej ziemskiego życia i wniebowzięciu; i one dzielą się tradycyjnie na ewangelie, dzieje apostolskie, listy i apokalipsy. Do najbardziej znanych i wpływowych należy Protoewangelia Jakuba (ClApNT 50), ułożona w 2. poł. II wieku w języku greckim, najprawdopodobniej w Egipcie przez chrześcijanina, a potem wielokrotnie przerabiana parafrazowana i tłumaczona na języki starożytne wschodnie (syryjski, koptyjski, armeński, gruziński, arabski i etiopski) i zachodnie (łacinę). Prostym językiem opisuje w 24 rozdziałach pominięte całkowicie w ewangeliach kanonicznych pierwsze lata życia Maryi, od chwili, kiedy anioł zapowiada jej narodzenie bezpłodnym rodzicom Joachimowi i Annie (tu po raz pierwszy podane ich imiona), aż do czasu, gdy Maryja opuszcza świątynię (gdzie była umieszczona po ukończeniu trzech lat), aby być powierzona przez władze świątynne Józefowi. Potem następuje opowiadanie o zwiastowaniu Maryi przy studni, odwiedzinach Elżbiety i rozpaczy Józefa, próbie gorzkiej wody, drodze do Betlejem i urodzeniu Jezusa, sprawdzaniu dziewictwa Maryi po urodzeniu Jezusa: przybyciu magów, ucieczce do Egiptu Maryi i Elżbiety oraz męczeńskiej śmierci Zachariasza z rozkazu Heroda. Celem autora tego apokryfu było wysławianie Maryi, Dziewicy i Matki, ze szczególnym podkreśleniem jej świętości, doskonałej czystości oraz absolutnego jej dziewictwa przed, w poczęciu i po urodzeniu Chrystusa ${ }^{11}$.

Do nie mniej znanych i wpływowych apokryficznych ewangelii maryjnych należą ponadto: Księga o narodzeniu świętej Maryi (ClApNT 52), napisana po

${ }^{10}$ Por. tamże VIII 357-358, ed. Kurfess, s. 778; GCS 8, 165; CMB I 356: „Siedem bowiem wieków pokuty wyznaczył Bóg grzeszącym ludziom przez ręce czystej dziewicy".

11 Por. Protoevangelium Jacobi, ed. K. Tischendorf, Leipzig 1876 (repr. Hildesheim 1966 i 1987), s. 1-50; CMP I 313-337, thum. M. Starowieyski, ANT ${ }^{2}$ I 266-290, lub thum. $z$ franc. Z. Romanowiczowa, w: D. Rops - F. Amiot, Apokryfy Nowego Testamentu, Londyn 1955, 3952; L.M. Peretto, La mariologia del Protovangelo di Giacomo, Roma 1955; tenże, Influsso del Protovangelo di Giacomo nei secoli I-IV, „Marianum” 19 (1957) 59-78; tenże, La Vergine Maria nel pensiero di un scrittore del secondo secolo, „Marianum” 16 (1954) 228-265; M. Jugie, Le „Protoévangile de Jacques” et l'Immaculée Conception, „Echos d'Orient” 14 (1911) 20-30; J.D. Kaestli, Le „Protoévangile de Jacques” latin dans l'homélie „Inquirendum est” pour la fête de la Nativité de Maria, „Apocrypha” 12 (2001) 99-154; R. Laurentin, Theologumena anticpateurs $d u$,Protoévangile de Jacques” du Symbole au dogme, w: Marie dans les récits apocryphes chrétiens, dz. cyt., s. 97-118; P.G.M. Roschini -M. Gabriele, I fondamenti dogmatici del culto mariano nel „Protovangelo di Giacomo”, w: De primordiis cultus mariani, IV, Romae 1970, 253-272; R. Winling, Le „Protévangile de Jacques” et Marie, w: Marie dans les récits apocryphes chrétiens, dz. cyt., s. 81-96; L. Cross, The Protoevangelium of James in the formulation of Eastern Christian Marian Theology, StPatr 40 (2006) 381-391; M. Starowieyski, Protovangelo di Giacomo Minore, NDPAC II 2150-2152 (bibliografia). 
łacinie w epoce karolińskiej, a opisująca narodzenie, pierwsze lata życia Maryi oraz jej zaślubiny z Józefem i bardzo krótko urodzenie Jezusa ${ }^{12}$, Ewangelia Pseudo-Mateusza lub Księga o narodzeniu błogosławionej Maryi oraz o dzieciństwie Zbawiciela (ClApNT 51), będąca najsłynniejszą przeróbką Protoewangelii Jakuba, powstała w języku łacińskim na początku VII wieku ${ }^{13}$; Ewangelia dzieciństwa (ClApNT 58) nazywana niekiedy Arabskim życiem Jezusa, powstała w języku arabskim na podstawie Protoewangelii Jakuba ${ }^{14}$; oraz Legenda o św. Józefie Cieśli (ClApNT 60) ${ }^{15}$.

$\mathrm{Z}$ apokalips natomiast maryjnych, które występują w dwojakiej formie: jako opisy eschatologicznych wizji Maryi lub jako opisy odejścia (transitus) Maryi z życia ziemskiego, najbardziej wpływowe są te drugie - transitus $M a$ riae. Jest to duża grupa (ponad 20) apokryfów, opisujących odejście (śmierć) Maryi z tego świata (por. ClApNT 100-177), których strukturę literacką przedstawił syntetycznie św. Grzegorz z Tours $(† 594)^{16}$.

W każdym z nich można wydzielić trzy części: najpierw wstęp informujący, że Maryja odczuwa bliskość śmierci, w związku z którą zbierają się z różnych stron świata apostołowie, by razem z nią czuwać. Potem następuje opis odejścia Maryi: przybywa jej Syn, zabiera jej dusze, a apostołowie dokonują pogrzebania jej ciała. W trzeciej wreszcie części następuje opis powtórnego przyjścia Syna, który dokonuje przeniesienia do nieba jej duszy i ciała. Tak tworzone apokryfy, najczęściej w języku greckim i łacińskim, były bardzo popularne i przekładane na wszystkie języki starożytnego świata (arabski, armeński, etiopski, gruziński, starosłowiański i syryjski), w których do dziś w dużej mierze przetrwały. Ukazują one rozwój wiary we Wniebowzięcie NMP od jej pierwocin przy końcu IV wieku do jej pełnego sformułowania na przełomie

12 Por. Libellus de nativitate Sanctae Mariae, ed. C. Tischendorf, Lipsiae 1853 (Hildesheim 1987), 113-121; ed. R. Beyers, CCAp 10, 268-333, thum. K. Obrycki, ANT² 1, 331-341; M. Starowieyski, Apocrifi della natività, NDPAC II 3426-3428.

${ }^{13}$ Por. Liber de ortu beatae Mariae et infantia Salvatoris (Pseudo-Matthaei Evangelium), ed. C. Tischendorf, Lipsiae 1853 (ristamp. Hildesheim 1987), 51-111; ed. J. Gijsel, CCAp 9, 277-481; CMP VI 7201-7292, tłum. H. Obrycki, ANT ${ }^{2}$ I 291-316; E. Amann, Le protevangile de Jacques et ses rémaniements latins, Paris 1910, 272-339.

${ }^{14}$ Por. Evangelium infantiae (arabice), ed. G. Tischendorf, Hildesheim 1987, 181-209 (przekład), tekst arabski: J.G. Thilo, Codex apocryphus Novi Testamenti, I, Leipzig 1932, tłum. W. Dembski, ANT ${ }^{2}$ I 405-439, lub we fragmentach Z. Romanowiczowa, dz. cyt., s. 73-83.

${ }^{15}$ Por. Historia Josephi fabri lignarii, wyd. w wersji arabskiej: A. Battista - B. Bagatti, Edizione critica del testo arabo della „Historia Josephi fabri lignarii” e ricerche sulla sua origine, Jerusalem 1978; w wersji łacińskiej: G. Tischendorf, Hildesheim 1987, 122-139; CMP V 5628-5643, thum. T. Hergesel, ANT ${ }^{2}$ I/2, 559-577 lub we fragmentach Z. Romanowiczowa, dz. cyt., s. 83-87; A. Boud'hors, Origine et portée du récit apocryphe copte intitule „Histoire de Joseph le charpentier”, w: Marie dans les récits apocryphes chrétiens, Médiaspaul 2004, 139-154; P.R. Gauthier, La Vierge Marie d'après l', Histoire de Joseph le charpentier”, w; De primordiis cultus mariani, IV, Romae 1970, 353-370; M. Starowieyski, NDPAC II 2332-2333.

${ }^{16}$ Por. Gregorius Turonensis, De gloria martyrum 4, PL 71, 780. 
VI/VII wieku, ich zaś najstarsze egzemplarze pojawiają się przy końcu V lub na początku VI wieku. Ich źródłem i prawzorem zdają się być jednak powstałe wcześniej (III w.?) utwory - etiopska Księga spoczynku (Liber requiei) i syryjska Księga o pogrzebie Maryi (Liber de exequiis), traktujące o jej śmierci, pogrzebie i przeniesieniu do nieba ${ }^{17}$.

Do najbardziej znanych „odejść Maryi” należą: Transitus Romanus (ClApNT 102) uważany za najstarszy tekst transitus, a będący skrótem syryjskiej Księgi o pogrzebie Maryi ${ }^{18}$; Transitus Jana Teologa (ClApNT 101) najpopularniejszy i jedyny utwór grecki powszechnie wykorzystywany w liturgii wniebowzięcia, powstały ok. 460 roku $^{19}$; przypisywany Józefowi z Arymatei a powstały prawdopodobnie w Egipcie Transitus Józefa z Arymatei (ClApNt $116)^{20}$, oraz najkrótszy i najpopularniejszy w świecie łacińskim Transitus Melitona (ClApNT 111) $)^{21}$.

Apokryfy maryjne wyrażając w mniej lub więcej prymitywny sposób przekonania i wiarę ludu chrześcijańskiego, nie tylko poświadczają wszystkie zasadnicze prawdy o Maryi - jej świętość, dziewictwo, macierzyństwo, wstawiennictwo i wniebowzięcie, ale również wywarły wielki wpływ na wykrystalizowanie się dwóch zasadniczych prawd (dogmatów) maryjnych: prawdy o niepokalanym poczęciu i prawdy o wniebowzięciu Najświetszej Maryi Panny. Na wykrystalizowanie się pierwszej ${ }^{22}$ wpłynęły przede wszystkim ewangelie dziecięctwa, zwłaszcza bardzo w starożytności popularna, przerabiana i tłumaczona Protoewangelia Jakuba, podkreślająca absolutną czystość i świętość ${ }^{23}$ oraz nieskazitelne dziewictwo Maryi przed, w czasie i po narodzeniu Jezu-

17 Por. Liber Requiei (ClApNT 154), ed. V. Arras, De transitu Mariae apocrypha aetiophicae, CSCO 342, 1-84 (tekst), CSCO 343, 1-54 (przekład laciński), lub CMP V 5679-5765; Libellus de exequiis BMV (ClApNT), ed. W. Wright, Contributions to the Apocryphal Literature of the New Testament, London 1865, 55-65 (tekst), $42-51$ (przekład).

${ }^{18}$ Por. Transitus graecus „, $R$ ”, ed. A. Wenger, L'Assomption de la Vierge dans la tradition byzantine du VI $I^{e}$ au $X^{e}$ siècle, Paris 1955, 210-240, thum. M. Starowieyski, ANT ${ }^{2}$ I/2, 782-798; M. Clayton, The Transitus Mariae: the tradition and its origins, „Apocrypha” 10 (1999) 74-98.

${ }^{19}$ Por. Liber de dormitione auctore Pseudo-Joanne Apostolo, ed. C. Tischendorf, Apocalypses apocryphae, Leipzig 1866 (repr. Hildesheim 1966), 95-112, thum. M. Starowieyski, ANT2 I/2, 799809; S. Mimouni, Dormition et Assomption de Marie. Histoire des traditions anciennes, ThH 98, Paris 1995; E. Cothenet, Traditions bibliques et apocalypti ques dans les récits anciens de la dormition, w: Marie dans les récits apocryphes chrétiens, Médiaspaul 2001, 155-178.

${ }^{20}$ Por. Liber de transitu auctore Pseudo-Josepho ab Arimathaea, ed. C. Tischendorf, Leipzig 1866 (repr. Hildesheim 1966), 113-123, tłum. M. Starowieyski, ANT² 1/2, 810-816; M. Starowieyski, NDPAC II 2329.

${ }^{21}$ Por. Liber de transitu auctore Pseudo-Melitone, ed. G. Tischendorf, Leipzig 1866 (repr. Hildesheim 1966), 124-136; ed. M. Haibach-Reinisch, Ein neuer „Transitus Mariae” des PseudoMelitos, Romae 1962, 63-87, thum. M. Starowieyski, ANT² I/2, 817-826, lub Z. Romanowiczowa, dz. cyt., s. 88-95.

22 Por. C.A. Rush, Outlines of Marys holiness in New Testament apocrypha, w: Virgo Immaculata, III, Roma 1955, 259-268. 
$\mathrm{sa}^{24}$. Na uwypuklenia zaś prawdy i dogmatu o wniebowzięciu NMP wpłynęły zasadniczo równie popularne apokryfy o odejściu (transitus) $\mathrm{Maryi}^{25}$, one to są pierwszymi świadkami wiary ludu w tę prawdę, a także poświadczają rozwój tej wiary we wniebowzięcie NMP od jej pierwocin w V wieku do jej pełnego sformułowania na przełomie VII i VIII wieku. Wśród źródeł uzasadniających ogłoszenie dwóch ostatnich dogmatów maryjnych - Niepokalanego Poczęcia (1854) i Wniebowzięcia (1950) NMP, ważne miejsce zajęły również wymienione wyżej apokryfy maryjne; niektóre $\mathrm{z}$ nich są także do dziś wykorzystywane jako teksty liturgiczne.

Apokryfy dziecięctwa, kierowane nierzadko przeciw doketom, przyczyniły się również do umocnienia prawdy o prawdziwym macierzyństwie NMP - że ona dała Synowi Bożemu prawdziwe ludzkie ciało, że była Bogarodzicą. Z nich poznaliśmy imiona rodziców Maryi - Joachima i Anny ${ }^{26}$, jej dziecięcy pobyt w świątyni, narodzenie się Jezusa w jaskini (ProtEwJ), a także umieszczenie go między wołem i osłem (EwPs-Mt). Apokryfy dziecięctwa, oraz wzmianki w apokryfach Starego Testamentu, w dziejach i listach apostolskich, przyczyniły się również do utrwalenia wiary w dziewicze poczęcie Chrystusa za przyczyną Ducha Świętego, a także pełne dziewictwo Maryi.

Apokryfy zaś odejścia (transitus) obok problemu wniebowzięcia zawierają także inne elementy teologii maryjnej: silne powiązanie życia Maryi i Chrystusa: opis jej wskrzeszenia podobny jest do zmartwychwstania Chrystusa - nowy grób w Getsemani, pozostawione szaty, trzy dni w grobie. Wskrzeszenie Maryi powiązane jest z Kościołem, czego oznaką jest przybycie 12 apostołów (symbol Kościoła) ze wszystkich stron świata: niosą oni Maryję do grobu, jak Izraelici Arkę Przymierza. Po odejściu Maryi odbywa się w ich obecności sąd nad nią, podczas którego Chrystus pyta ich, co ma z nią uczynić, oni zaś proszą o jej wniebowzięcie. Opis wędrówki Maryi po piekle (ApokM) i jej skuteczne wstawiennictwo u Boga za potępionymi, a także liczne cuda zdziałane na jej prośbę (EwDzArab, ApoKTransJTeol) poświadczają prawdę o jej pośrednictwie.

Apokryfy maryjne wpłynęły także na powstanie kilku liturgicznych świąt maryjnych, jak: Święto Narodzenia NMP, Święto Prezentacji Maryi w świątyni,

${ }^{23}$ Por. R. Beyers, La réception médiévale du matériel apocryphe con cernant la naissance et la jeunesse de Marie, w: Marie dans les récits apocryphes chrétiens, Médiaspaul 2001, 179-200; G.D. Spirito, L'Annonciation de Sainte Marie, „Apocrypha” 7 (1997) 273-292.

${ }^{24}$ B. Bagatti, La verginità di Maria negli apocrifi del II-III secolo, „Marianum” 33 (1971) 281292; E. Cothenet, La virginté de Marie dans les apocryphes, w: La virginité de Marie, Paris Médiaspaul 1998, 53-69; E. Norelli, La Vergine Maria negli apocrifi, w: C. Leonardi -A. Degli Innocenti (ed.), Maria: Vergine, Madre, Regina, Roma 2000, 21-42.

${ }^{25}$ Por. D. Baldi - A. Mosconi, L'Assunzione di Maria negli apocrifi, w: Studia Mariana, I, Roma 1948, 73-125; B. Outtier, Dormition et Assomption de Marie, „Apocrypha” 9 (1998) 301-304.

${ }^{26}$ Por. J. Evenou, Des apocryphes à la liturgie. Les origines du culte de sainte Anne, w: Marie dans les récits apocryphes chrétiens, Médiaspaul 2001, 201-226. 
Święto Imienia Maryi, Święto Joachima i Anny itd. Wpłynęły one również w ogromny sposób na ikonografię maryjną ${ }^{27}$.

\section{DE MARIA IN APOCRYPHIS VETERIS TESTAMENTI}

(Argumentum)

Hac in dissertatiuncula, quae duobus partibus constat, primum fusius veritates de Maria (imprimis eiusdem virginitas) in apocryphis Veteris Testamenti, qui mariales a nonnulis vocantur (Testamentum XII Patriarcharum, Ascensio Isaiae, Odae Salomonis, Oracula Sibyllina) exponuntur, deinde influxus apocryphorum Veteris et Novi Testamenti generaliter in mariologiam catholicam constituendam concise demonstratur.

27 M. Starowieyski, Kulturotwórcza rola apokryfu, w: Idee chrześcijańskie w życiu Europejczyka, cz. 1, Łódź 2001, 63-76. 